\title{
Importance of Contract Administration for Timely Construction of Hydropower Projects without Disputes
}

\author{
Gyanendra Prasad Kayastha
}

\begin{abstract}
Most of the large hydropower projects in the region have been behind schedule than agreed in the contracts. Such delays besides project cost overrun cause direct economic loss to the countries in the form of interest costs, loss of energy revenues and loss in industrial production due to shortage of power. With delays, the Contractor finds ways for claim for additional time and cost. Such a situation may be the result of poor contract administration \& management skills. Therefore, a fair and just administration of the contract is key to the successful performance of the contract on time, with respect to both budget and quality with minimum dispute events.
\end{abstract}

Key words: Contract administration, claim, disputes, time and cost overrun, quality

\section{Contract Procurement}

Zfficient contract procurement is a prerequisite $E_{\text {to }}$ efficient contract administration. Adequate procurement planning, timely decision making in selecting a qualified Engineer for design and supervision of the project and award of the contract to a competent Contractor are amongst essential elements in the initial phase of project management. The selection and employment of a competent and reputable Consultant (Engineer) is of paramount importance. Bidders take into account the reputation of the Engineer while preparing their bids weighing the prospects of prompt actions and impartial treatment from the Engineer in contract implementation. The Engineer's reputation in respect of impartiality and quick decisions, including speedy certification for payment will produce a competitive bid price. Most contracts are based upon the International FIDIC Conditions of Contract suitably tailored to the contract specific requirements.

\section{Delegation of Authority by the Employer to Engineer}

The bidding/contract documents must spell out the extent of authority the Employer intends to delegate to the Engineer. The delegation must be appropriate to the circumstances of the project and the experience of the Employer. Too much delegation of authority to the Engineer may result in the Employer being bypassed on important issues. On the other hand, too little delegation places the burden of decision making on many day to day contractual matters directly in the hands of a probably already overburdened Employer's top management and its Project Management entity. It is a useful practice to introduce appropriate control on the delegated authority of the Engineer, requiring consultation with and approval of the Employer before action is taken on important matters such as Subcontracting parts of the Works, certifying additional time and or costs for unforeseen physical conditions, granting an extension of time for reasons beyond the control of the Contractor, ordering extra works or variations necessary for the completion of the intended works and agreeing to new unit rates and prices for variations etc.

\section{Contract Award}

The primary objective of contracting is that a skilled Contractor shall be employed to perform the works in order to relieve the Employer from carrying out construction operations and management thereof. Proper selection of Contractors through pre-qualification and contract award decisions made judiciously are, therefore, of paramount importance. Pursuant to good practices, an award of the contract should go in favor of the qualified bidder offering the lowest evaluated responsive bid. It is, however, not uncommon to receive irresponsibly low rates in bidding. Efforts to achieve fair pricing by drawing away from cut throat competition through bracketing have been made in several countries in the past.

\section{Contract Administration}

Contract is a mutual agreement between two parties. The contract conditions therefore should be framed on the basis of equity and withth out bias. In the present scenario of hydropower projects, it has been observed that there is vast scope for reviewing the conditions while formulating the contract. The conditions of contract carry much importance as the whole works throughout are executed in accordance with those conditions.

Clear and unambiguous provisions in the contract are essential for the timely completion of the projects without any or minimum disputes. This will minimize the conflict between the Employer and the Contractor and will activate good relationship between them. The probability of cropping up of disputes can be effectively reduced by framing judicious, clear and unbiased conditions of the Contract. However, if at any point of time a dispute crops, the clear provisions of the contract will be certainly more useful to resolve the same, rather than some vaguely drafted conditions of the contract.

The Contract creates rights, responsibilities of the contracting parties applicable to each other. Success depends upon the intention and conduct of the parties. It is not for nothing that some one said, "A construction contract is like a marriage, a long term undertaking requiring a lot of understandings, care and respect for each other. It needs lots of efforts to keep the fruits and it 
is very expensive to break".

\section{Employer, Engineer and the Contractor in Contract Management}

The contract between the Employer and Contractor sets out the rights and obligations of the parties that guide and manage their roles. As the Engineer is not a party to the contract, it would be the responsibility of the Employer to ensure that the Engineer duly performs the assigned duties as an independent and impartial body. The Engineer's independent decisions must reveal that they have been taken impartially.

\section{FIDIC Contract Clauses - Potential of Giving Rise to Claims}

There are over 21 FIDIC Clauses/Sub - Clauses pursuant to which claims can be lodged for additional payment and/ or extension of time of completion. Most of these clauses empower the Engineer to determine the Contractor's entitlement. Only a few areas with the potential to give rise to claims are discussed in brief hereunder.

\section{Clause related to Drawings}

Where the drawings are to be provided by the Engineer, they should be issued promptly so that the work of the Contractor is not delayed and disrupted. If the Engineer fails to issue the drawings within a reasonable time and the Contractor's work is delayed, the Contractor may or should give notice to the Engineer to that effect with a copy to the Employer.

\section{Clause related to Physical Obstruction}

Change in the physical conditions may lead to additional post contract work, change in construction methodology, delay in completion and the liability to third party. Lack of adequate pre-bid investigation by the Employer is the main reason for claims arising under this clause.

Therefore, if during the works execution the Contractor encounters physical obstruction or conditions which, in his opinion, could not have been reasonably foreseen, he should as early as possible give notice thereof to the Engineer and the Employer with intention to make a claim for extension of time and cost.

\section{Clause related to Suspension}

More common claims arising out of this clause are related to difference of opinion on suspension of works. Suspension ordered for reasons other than that stated in the clause including some default or breach of contract by the Employer would be compensable in terms of time and associated costs.

\section{Clause related to Possession of Site}

It is an established principle and also provided for in this clause that unless the contract specifies time or dates, the Employer is to hand over possession of as much of the site and the means of access to enable the Contractor to proceed with his program submitted after the Contract signing and accepted by the Engineer. If such a program does not exist, the possession of the site should be within a reasonable time. The Employer's failure to give possession of the site on time entitles the Contractor to an extension of time for completion under the clause related to time extension. The Contractor's entitlement to costs is to be considered under a separate clause.

Failure to give possession of the site on time, if time extension provision were not there, would debar the Employer's entitlement to liquidated damages.

\section{Clause related to Extension of Time}

This provision is of general nature related to the Contractor's entitlement to the extension of time for completion of the work provided the causes of delay are not attributable to the Contractor's conduct. The Contractor is required to give notice to the Engineer and provide details within the time period specified thereunder.

\section{Clause related to Variation and its Valuation}

Variation is a much talked about topic these days. It is commonly perceived that variations involve corruption. It is, however, universally recognized that major civil Engineering Contracts can not be successfully completed without making certain indispensable but previously unforeseen changes to the design and specifications, and sometimes to the method of execution during implementation.

\section{Clause related to Termination of Contract}

The FIDIC Condition of Contract clause gives the Contractor the right to terminate the contract or to suspend the works, if the Employer fails to make payment against a certification within the specified time or interferes with certificates. The Contractor may give a notice that unforeseen economic circumstances have rendered it impossible for him to continue. The Contractor may terminate the contract upon giving 14 days notice to the Employer.

\section{Delays in Hydropower Projects}

Different types of delays are encountered in hydropower projects. The delays are caused either by the default of the Employer or by the default of the Contractor. If the delays are caused by the Employer in respect of the nonfulfillment of the Employer's obligations as mentioned above, these delays lead to the Contractor's request for time extension with cost reimbursements. Often, these claims lead to the disputes. They are described below:

\section{Kulekhani-III Hydroelectric Project (14 MW) being constructed under FIDIC IV Red Book}

The Contractor's dispute with the Employer/Engineer is related to an extension of time and claim for the payment of costs due to delay caused by reasons other than due to the Contractor. The list of the claims is given below:

- Suspension of Works due to Civil Disorder. 
- Delay in Site Possession or Access to Site for Adit Nos. 2 \& 3.

- Delay in Powerhouse: Access to Site Possession, Local Disruption.

- Delay in Site Possession: Access to Site for Adit 4.

- Delay in Site Possession of Intake and Work Suspension of the Intake Portal.

- Unforeseeable Physical Obstruction Encountered at Head Race Tunnel.

- $\quad$ Low Voltage Supply.

Chameliya Hydroelectric Project (30 MW) being constructed under FIDIC IV Red Book

The Contractor filed a claim seeking extension of time and cost compensation due to delays caused by the change of location of the powerhouse and change of method of its excavation etc. The list of the some of the claims is given below:

- Change of Location of Powerhouse.

- Change of Method of Excavation at Powerhouse.

- Delays and Disruption to Surge Tank, Diversion Tunnel, Dam and Spillway etc.

- Suspension of Work due to the Safety Issues.

- Lack of Possession of Site.

- Lack of Construction Drawings for Construction of Road to Adit 3.

Trishuli 3-A Hydroelectric Project (60 MW) being constructed under FIDIC 1999 Silver Book

As per Memorandum of Understanding, the Employer intended to issue the Notice to Commence on or before 1 June 2010 but the Contractor received the Notice to Commence only on 1 June 2011. Due to the reasons beyond control, the Contractor submitted the following claim for compensation due to the delay of one year in the issuance of Notice to Commence by the Employer.

- Compensation for Costs citing Sub-clause 8.5: Delays caused by Authorities.

\section{Rahughat Hydroelectric Project (32 MW) being constructed under FIDIC 1999 Red Book}

As per the contract agreement between NEA and IVRCL signed on 04.11.2010, the Contractor was allowed to start the road work only and its supervision would be carried out by the Employer. It was mentioned in the Memorandum of Understanding (MoU) that the Consultant would be mobilized in six months time. Due to various reasons, the Consultant could not be mobilized as stated in the MoU. The consultancy services for the construction management and construction supervision became effective only from 16.08.2012. The Engineer M/s WAPCOS issued the Notice to Proceed (NTP) on 30.11.2012 to the Contractor for starting the main civil works but the Contractor did not accept the NTP. Instead, the Contractor put forth the different issues on 04.12.2012 requesting for settlement of these issues prior to start of the works. Following are some of the issues put forward by the Contractor:
- Compensation for the losses due to delayed start of the works.

- Increase in the BoQ materials by $50 \%$ due to abnormal increase in prices.

- Removal of 25\% Price Adjustment Ceiling.

\section{Conclusions and Recommendations}

The Procurement function is unique to each project and has a heavy downstream effect during implementation. It is, therefore, essential that the staffs of contracting parties involved in this function should be specialized, experienced and trained.

Many disputes have been noticed as a result of the Employer's default during the performance of the contract as seen from the above listed disputes. Past experiences have shown that the Employer is not aware of the important issues to be addressed. Therefore, the Employer has to focus on the above mentioned important clauses which are potential to generate claims.

It is fundamental that the contract documents are clear and as brief as possible, incorporating balanced risk sharing provisions between the Employer and the Contractor. Design based on adequate site investigation, clear and complete specifications, well defined performance standards and a Competent Engineer will help in efficient contract administration with minimum dispute.

Delays in decision making at the contract procurement and administration stages are immense. Such delays multiply when the Employer assumes both roles. Therefore, the required land acquisition must be completed in advance of contract agreement so that timely handover of the sites is made to the Contractor. It is also a must to appoint the Consultant prior to the Civil Contract Agreement for the proper supervision and contract administration by the Engineer to avoid any dispute and delays in contract execution.

Lack of proper coordination between the Employer's related entities, including local civil authorities adversely influences the construction progress and hence, the Employer should coordinate with the concerned authorities on time for the smooth implementation of the project.

Gyanendra Prasad Kayastha, M.Sc. (Construction Management) is a Civil Engineer graduated from Roorkee University, India in 1984. He has received training in hydropower development and management, contract management \& administration, FIDIC Condition of Contracts 1987, 1999, 2006, 2010 (Red, Yellow and Silver) and claim management, dispute resolution and arbitration from Nepal and abroad. He has been working with Nepal Electricity Authority since 28 years and has experiences in the design, construction supervision, operation \& maintenance and

Continued in page 58 


\section{Acknowledgement}

The authors gratefully acknowledge the support of Dr. Appu Kuttan K.K., Director Maulana Azad (National Institute of Technology, Bhopal, India) to carry out this research work.

Shambhu Ratan Awasthi, graduated in electrical Engineering in 1971 and obtained his Master's degree in Design of Heavy Electrical Equipment. He joined as Design Engineer at Bharat Heavy Electricals Limited, Bhopal, India where he was finally elevated to the post of General Manager prior to his superannuation in 2010. He has 36 years of rich experience in the design of Hydro-generators, Project Management of power projects and field experience of hydropower plants in India and abroad. He has two books and more than 20 published papers at his credit in the field of his specialization.

Corresponding address: srawasthi269@yahoo.com

Dr. Vishnu Prasad, has 24 years teaching and research experience and presently working as Professor and Head, Department of Civil Engineering, MANIT, Bhopal (India). He has specialization in hydro power and water resources engineering. He has published about 75 papers in International, national journals and conferences. He has supervised M.Tech. and Ph.D. candidates in hydropower engineering and organized conferences. He has expertise in model testing and numerical simulation of hydraulic machines and contributed a lot in consultancy in this area. He has visited UK for six months training in the area of hydro power under Indo-UK RECs Project.

Dr. Saroj Rangnekar, is Professor in Department of Energy, Maulana Azad National Institute of Technology (MANIT), Bhopal, India. She has 34 years of teaching and research experience and received three National awards. Her field of interest includes real time control of
Energy Systems, Integrated Energy Systems Modeling, Simulation, Optimization etc.

\section{References}

Arce, A., T. Ohishi and S. Soares, 2002, 'Optimal dispatch of generating units of the Itaipú hydroelectric plant', IEEE Trans. Power Systems 17(1).

Diniz, A. L., P. P. I. Esteves and C. Sagastizábal, 2007, 'A Mathematical Model for the Efficiency Curves of Hydroelectric units', IEEE PES General Meeting, Tampa, FL, pp. 1-7.

Finardi, E. C. and E. L. Silva, 2005, 'Unit commitment of single hydroelectric plant', Electric Power Systems Research 75(2-3):116-123.

Galvis, J. C., A. Padilha-Feltrin and J. M. Y. Loyo, 2011, 'Cost assessment of efficiency losses in hydroelectric plants', Electric Power Syst. Research 81(10):18661873 .

Nilsson, O. and D. Sjelvgren, 1997, 'Variable splitting applied to modeling of start-up costs in short term hydro generation scheduling', IEEE Transactions on Power Systems 12(2):770-775.

Pérez-Díaz, J. I, J. R. Wilhelmi and J. A. SánchezFernández, 2010, 'Short-term operation scheduling of a hydropower plant in the day-ahead electricity market', Electrical Power Systems Research 80(12):1535-1542.

Soares, S. and C. T. Salmazo, 1997, 'Minimum loss predispatch model for hydroelectric power system', IEEE Transactions on Power Systems12 (3):1220-1228.

Soares, S., T. Ohishi, M. Cicogna and A. Arce, 2003, 'Dynamic dispatch of hydro generating units', IEEE Bologna PowerTech Conference, 1-6.

Sousa, T., J.A.Jardiniand R. A. Lima, 2007, 'Hydroelectric Power Plant Unit Efficiencies Evaluation and Unit Commitment', IEEE Bologna PowerTech Conference, 1368-1373.

\section{Continued from page 51}

contract administration. He is presently involved with the dispute resolution process with the Contractors in different hydropower projects undertaken by NEA.

Corresponding address: gkayastha@hotmail.com

\section{References}

Brian W. Totterdill - A practical guide to the 1999 Red and Yellow Books.

E.C Corbett - FIDIC $4^{\text {th }}$ A Practical Legal Guide.

Guide to the Use of FIDIC, Conditions of Contract for
Civil Engineering Construction - Fourth Edition

Nael G. Bunni - The FIDIC Form of Contract -Fourth Edition of Red Book.

Proceedings of $6^{\text {th }}$ International Conference on Development of Hydropower- A Major Source of Renewable Energy organized by International Association on Electricity Generation, Transmission and Distribution, June 7-9, 2005, Kathmandu, Nepal.

Status of Claim Situation of Hydropower Projects being undertaken by Nepal Electricity Authority. 